\title{
PROSES SOSIAL SEBAGAI AKAR SUBLIMASI MASYARAKAT PEDESAAN
}

\author{
Budiman Pohan, Wahju Gunawan \\ ${ }^{1}$ Pasca Sarjana Sosiologi, FISIP, Universitas Padjadjaran \\ 2Jurusan Sosiologi, FISIP, Universitas Padjadjaran
}

budiman18001@mail.unpad.ac.id

\begin{abstract}
The social process is the main basis in forming cooperation and compromise to provide prospects for the achievement of community needs, especially for isolated villages and difficulty accessing public facilities. So it is important for rural communities to improve their level of social processes to more sophisticated levels of resource management. This study aims to determine the characteristics of social processes as a basis for sublimation of rural. This study uses a qualitative approach. Informants were taken purposively with categories of community members, local elites, and village officials. The results showed that the social processes of the Mekarwangi Village community were associative, such as patron-client, mutual cooperation, savings and loans in cooperatives, and annual celebrations. While the dissociative process is in the form of rumors, frictions of political interests, and difficulties of bureaucratic and technological accessibility. The role of the village government in developing socio-economic infrastructure is still minimal due to administrative and funding constraints. Thus, economic empowerment and infrastructure development programs must be supported by the discretion of the village apparatus and community donations. Therefore, sublimation reorientation needs to be done from the bureaucratic and technocratic aspects, in order to diversify agricultural production and encourage sustainable development.
\end{abstract}

Keywords: relation, social process, role-status, sublimation, rural community

\begin{abstract}
Abstrak
Proses sosial merupakan basis utama dalam membentuk kerjasama dan kompromi untuk memberikan prospek pencapaian kebutuhan masyarakat, terutama bagi desa terisolir dan sulit mengakses fasilitas publik. Maka penting bagi masyarakat pedesaan untuk meningkatkan taraf proses sosialnya ke tingkat pengelolaan sumber daya yang lebih mutakhir. Penelitian ini bertujuan untuk mengetahui karakteristik proses sosial sebagai basis sublimasi masyarakat
\end{abstract}


pedesaan dalam menghadapi tantangan pembangunan. Penelitian ini menggunakan pendekatan kualitatif. Informan diambil secara purposif dengan kategori anggota masyarakat, elite lokal, dan aparatur desa. Pengumpulan data melalui observasi, wawancara mendalam, dan dokumentasi. Hasil penelitian menunjukkan bahwa proses sosial masyarakat desa Mekarwangi bersifat asosiatif, seperti patron-klien, gotong-royong, simpan-pinjam di koperasi, dan hajatan tahunan. Sedangkan proses disosiatif berupa desas-desus, friksi kepentingan politik, dan kesulitan aksesibilitas birokrasi dan teknologi. Adapun peran pemerintah desa dalam mengembangkan infrastruktur sosial-ekonomi masih minim karena terkendala administrasi dan pendanaan. Sehingga, program pemberdayaan ekonomi dan pembangunan infrastruktur mesti didukung oleh diskresi aparatur desa dan donasi masyarakat. Oleh karena itu, reorientasi sublimasi perlu dilakukan dari aspek birokratis dan teknoratis, guna mendiversifikasi produksi pertanian dan mendorong pembangunan berkelanjutan

Kata Kunci: hubungan, proses sosial, status-peran, sublimasi, masyarakat desa

\section{PENDAHULUAN}

Kajian masyarakat pedesaan hakikatnya berupaya mengidentifikasi kekuatan-kekuatan lokal yang melestarikan solidaritas sosial beserta daya tahannya dalam menghadapi problem sosial. Kondisi status quo versus pembangunan yang dinamis mengindikasikan adanya anasir-anasir perubahan yang dapat menimpa anggota masyarakat pedesaan. Sehingga, sangat sulit menafikan stabilitas masyarakat tetap utuh dari masa ke masa. Premis semacam ini tetap dipegang oleh akademisi sebagai upaya menegakkan prinsip kebaharuan dalam penelitian yang layak dan relevan bagi publik.

Selama ini, isu masyarakat pedesaan dari perspektif proses sosial telah banyak dibahas oleh peneliti sebelumnya. Interaksi sosial dalam konteks mobilitas pendatang dengan masyarakat lokal kerapkali dikaji secara kontinyu. Kehadiran kaum urban dapat diterima dengan basis toleransi yang kuat dan dapat membentuk hubungan positif dengan masyarakat setempat (Fitriani, 2014). Kolaborasi antara pendatang dengan masyarakat lokal justru menguntungkan terutama dalam penyelenggaraan acara keagamaan (Halik, 2014). Sebut saja target kunjungan kaum urban maupun pendatang diasumsikan untuk berkarir atau sekedar mengunjungi situs-situs sakral (Mutmainnah, 2009). Meskipundemikian, kaum urban dengan masyarakat desa mulanya akan membangun hubungan yang relatif berjarak untuk menghindari resiko konflik (Nurcahyaningsih, 2014). Dalam hal ini, hubungan kaum urban dengan masyarakat desa masih pada taraf kepentingan-kepentingan temporal dan belum mengarah pada suasana pluralistik.

Masyarakat desa cenderung mengamplikasikan pola hubungan dan proses sosial yang relatif homogen. 
Namun, semenjak terbukanya akses setiap individu ke berbagai lokasi maka peluang terbentuknya pluralitas masyarakat desa sangat terbuka lebar. Untuk meminimalisasi resiko tersebut, maka akomodasi dapat menjadi solusi untuk menyeimbangkan perbedaanperbedaan kepentingan (Muslim, 2013). Peluang pluralitas pada masyarakat desa bisa menguntungkan karena memperluas kepentingan kekeluargaan, kepentingan agrobisnis, kepentingan penyedia jasa dan fasilitas, serta peningkatan mutu informasi (Syahir, 2015; Masuku, Pattiselano, \& Thenu, 2017). Bahkan, distingsi keagamaan dapat ditolerir secara gradual selama kaum urban dan masyarakat desa menghindari aksi dominasi etnis (Khotimah, 2016), sekaligus memperkuat ikatan kekeluargaan dengan saling bergotongroyong dan menghargai akidah masingmasing (Sukardi, 2015; Syaifudin, 2017).

Penelitian terdahulu di atas berfokus pada eksistensi pihak eksternal turut mempengaruhi proses sosial di lingkup internal masyarakat pedesaan sebagai konsekuensi pengembangan kapasitas bersama. Proses pertimbangan memicu harapan untuk berkolaborasi dengan individu lain (Rahman, 2011: 35). Berlangsungnya proses sosial sematamata untuk memenuhi kebutuhan manusia yang bersifat inklusif, kontrol sosial, dan afeksi (kasih sayang). Di sisi lain, proses sosial menghasilkan perubahan mendasar yang menciptakan mobilitas gerakan sosial; terciptanya kelompok, asosiasi, organisasi, dan partai politik baru; tersebarnya gaya hidup baru; dan berkembangnya temuan teknologi dengan segala dampaknya (Sztompka, 2014: 16).
Pernyataan di atas mendeskripsikan proses sosial juga berkaitan erat dengan koeksistensi mikroskopik dalam memproteksi kualitas kearifan lokal masyarakat setempat. Padahal, ada sejumlah tantangan masyarakat pedesaan yang mesti dikalkulasi terkait dengan perubahan sosial yang relatif bersinggungan secara makroskopik. Perihal tersebut, eksistensi desa sarat akan turbulensi, apabila bertahan dari kebiasaan menandakan ketertinggalan budaya dan teknologi, jika menerima perubahan maka bersiap dengan resiko modernisasi dan distingsi kultural.

Kehendak perubahan sosialekonomi diawali dengan tesis sejauh mana produktivitas pertanian dapat memenuhi taraf hidup masyarakat. Salah satunya dengan mendorong pengolahan sumber daya ke tingkat yang lebih kompleks. Keajegan produksi pertanian yang monoton jelas menyulitkan manusia memaksimalkan pendapatan keluarga, Sedangkan biaya hidup terus meningkat secara gradual dan tuntutan kebutuhan mengalami diferensiasi. Pada akhirnya, masyarakat desa akan berpikir untuk menyesuaikan tuntutan regional maupun global dengan mengalihfungsikan lahan ke sektor yang lebih deterministik dengan asumsi dapat mendatangkan profit yang lebih bergengsi (Dharmawan, 2007; Williams \& Schirmer, 2012).

Tren alih fungsi lahan akan dimanfaatkan oleh pihak kapital dengan membeli dan mendominasi tanah serta membuka jenis pekerjaan baru, seperti bisnis sewa tanah, buruh tani, dan lapangan industri. Hal ini akan "memaksa" pola pembagian kerja masyarakat desa dari mekanis ke organis. Kebutuhan spesialiasi semacam ini, jelas 
menambah daftar varian profesi warga yang mesti terpenuhi (Effendi, 2013; Rahman, 2016).

Asumsi perubahan kultural akan beralih ke perubahan struktural terkait dengan performa aparatur desa dalam menyusun kebijakan. Aparatur desa mesti berdiri pada poros netralitas dalam menyikapi kepentingan segelintir kelompok dan menjauhi "transaksi di bawah meja". Selain itu, aparatur desa perlu mensinkronisasikan kebijakan dengan perubahan karakteristik proses sosial masyarakat desa. Pelibatan kelompok di tingkat elite lokal, kapital, dan grassroot perlu dilakukan untuk mengantisipasi dan meningkatkan kesejahteraan sosial (Mocodompis, 2014).

Sekelumit persoalan tersebut persis dialamiolehmasyarakatdesaMekarwangi yang mengalami akulturasi etnisitas non-signifikan. Namun, kesejahteraan sosial perlu dicapai dengan kreativitas proses sosial masyarakat desa untuk meraih dan menstabilkan perubahanperubahan struktural ke tingkat yang lebih tinggi atau yang disebut sublimasi. Pencapaian sublimasi bukan sekedar uraian simplistik terhadap kondisi terkini objek yang diteliti, tetapi secara eksklusif mendisposisikan proses sosial sebagai basis utama dari pergulatan dinamis individu dan kelompok.

Sejauh pengamatan peneliti, kondisi masyarakat pedesaan memiliki pola interaksi yang menciptakan situasi statis sekaligus dinamis tergantung pada variabel-variabel yang dipersoalkan oleh anggota masyarakat, serta daya dukung yang menjaga koeksistensi kultural sekalipun diterpa oleh tantangan pembangunan. Oleh karena itu, penelitian ini bukan hanya mengidentifikasi karakteristik proses sosial masyarakat desa Mekarwangi, Kecamatan Sindangkerta, Kabupaten Bandung Barat, tetapi juga mengevaluasi dan memprediksi proses sublimasinya.

\section{METODE}

Penelitian ini menggunakan pendekatan kualitatif dengan metode deskriptif. Teknik pengumpulan data melalui wawancara mendalam, observasi, dan studi dokumentasi. Hal ini dilakukan untuk mengetahui karakterteristik proses sosial dan status sublimasi masyarakat desa Mekarwangi Kecamatan Sindangkerta, Kabupaten Bandung Barat. Informan dipilih secara purposive meliputi anggota masyarakat, tokoh masyarakat, dan aparatur desa yang dipandang berpengetahuan dalam menjelaskan persoalan yang hendak diteliti. Triangulasi data dilakukan cross-check melalui tinjauan lapangan, dokumentasi, dan Focus Group Disscussion (FGD) dengan kepala desa dan KASI Kesejahteraan untuk memverifikasi informasi yang telah dikumpulkan. Setelah itu dilakukan analisis sosial dengan mengkategorisasi data-data yang ada dan diinterpretasikan menggunakan perspektif proses sosial dan sublimasi masyarakat pedesaan

\section{III.HASIL DAN PEMBAHASAN}

\subsection{Selayang Pandang Kondisi Desa Mekarwangi}

Desa Mekarwangi, Kecamatan Sindangerta merupakan desa yang berada di kaki Gunung Tangbak Ruyung di mana mata pencaharian penduduknya dari dulu hingga sekarang mayoritas 
bercocok tanam. Perbedaannya di masa lampau menggunakan alat bercocok tanam sederhana dibandingkan sekarang. Masyarakat hanya bercocok tanam dengan tanaman yang tumbuh secara alami tanpa melakukan inovasi pertanian atau perkebunan. Pada tahun 1900 sampai sekarang masyarakat sudah dapat bercocok tanam secara mandiri. Sumber lain menerangkan mulai dari tahun 1945 setelah Republik Indonesia merdeka, penduduk desa Mekarwangi selain bercocok tanam atau bertani ada pula yang beternak sapi, domba, kerbau, ayam, kambing, dan lainnya.

Catatan sejarah menyebutkan bahwa desa Mekarwangi merupakan desa hasil pemekaran dari desa Wangun, dimana pemekarannya dimulai sejak tahun 1983 dankepaladesasementaradijabatpertama kali oleh Suhandi yang merupakan pejabat Pemda Kabupaten Bandung. Di tahun yang sama pasca pemekaran, desa Mekarwangi melakukan pemilihan kepala desa. Proses pemilihan pertama kali diduduki oleh Atang Rudayat yang sebelumnya dipandang sebagai salah satu sesepuh masyarakat Mekarwangi. Atang Rudayat melakukan gebrakan dengan melakukan pembangunan secara sederhana dan bertahap guna mensejahterahkan masyarakat dengan mengandalkan sumber daya desa seadanya. Setidaknya infrastruktur dasar yang dapat menunjang aktivitas sosialekonomi masyarakat.

Daerah Mekarwangi merupakan daerah yang subur untuk bercocok tanam sehingga selain penduduk asli lambat laun daerah ini juga didatangi oleh penduduk dari luar desa yang berkeinginan ikut bercocok tanam di kawasan ini. Sehingga, berangsur-angsur kehidupan sosial budaya semakin kompleks dan beranekaragama. Sumber pendanaan desa berasal dari pemerintah maupun sumber pendanaan lainnya yang berasal dari urunan desa.

Pemerintahan desa juga mengalami pergulatan demokratis dan telah mengalami pergantian kepemimpinan. Hal ini berlangsung dari tahun 1990-an hingga sekarang. Nama-nama Kuwu atau kepala desa setelah pemekaran dari Desa Wangun, diantaranya: (1) Atang Rudayat (1984-1992); (2) Pjs Rohman (1992-1993); (3) Atang Rudayat (1994-1998); (4) Pjs Maud (1998-1999); (5) Edi Rohimat (1999-2013); dan (6) Nina Sutarsih (2014-sekarang). Adapun mengenai komposisi administratif yang membatasi desa Mekarwangi secara geografis dapat dilihat pada tabel di bawah ini:

TABEL 1. Batas Wilayah Desa Mekarwangi

\begin{tabular}{|c|c|c|}
\hline Batas & $\begin{array}{c}\text { Desa/ } \\
\text { kelurahan }\end{array}$ & Kecamatan \\
\hline $\begin{array}{l}\text { Sebelah } \\
\text { Utara }\end{array}$ & $\begin{array}{l}\text { Desa } \\
\text { Wangunsari }\end{array}$ & Sindangkerta \\
\hline $\begin{array}{l}\text { Sebelah } \\
\text { Selatan }\end{array}$ & Desa Rancabali & Rancabali \\
\hline $\begin{array}{l}\text { Sebelah } \\
\text { Timur }\end{array}$ & $\begin{array}{l}\text { Desa } \\
\text { Lebakmuncang } \\
\text { dan Desa } \\
\text { Rawabogo }\end{array}$ & Ciwidey \\
\hline $\begin{array}{l}\text { Sebelah } \\
\text { Barat }\end{array}$ & $\begin{array}{l}\text { Desa } \\
\text { Gununghalu }\end{array}$ & Gununghalu \\
\hline
\end{tabular}

Sumber: Profil Desa Mekarwangi 2018

Adapun visual wilayah administratif Desa Mekarwangi dapat dilihat pada peta berikut ini:

Desa Mekarwangi dapat dikategorisasikan sebagai desa berkembang. Potensi serta segala 
keunikan yang dimiliki masih perlu diidentifikasi lebih lanjut, terlebih struktur sosial yang masih dinamis dan dapat diperbaharui. Adapun mengenai kondisi objektif Desa Mekarwangi baik secara geografis, demografis, maupun sosial budaya telah dirangkum dalam format tabel berikut ini:

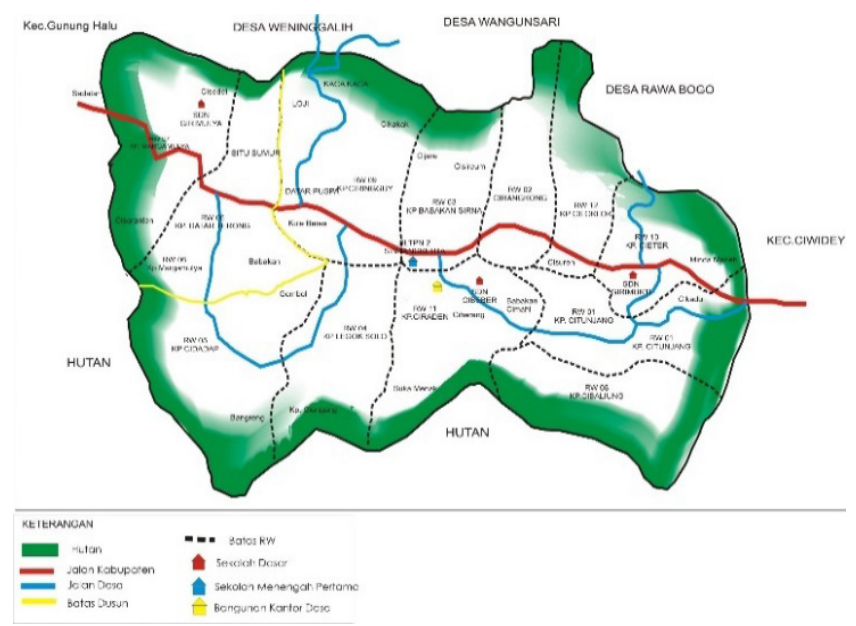

TABEL 2. Gambaran Umum Kondisi Desa Mekarwangi

\begin{tabular}{|l|l|}
\hline Item Penilaian & \multicolumn{1}{|c|}{ Kondisi Desa Mekarwangi } \\
\hline Geografis & $\begin{array}{l}\text { Luas wilayah 4.542,33 hektar; akses mudah ke luar mudah, sulit ke } \\
\text { balai desa; memiliki 8 aliran sungai atau selokan; didominasi oleh } \\
\text { permukiman, pertanian, dan perkebunan }\end{array}$ \\
\hline Demografis & $\begin{array}{l}\text { Total penduduk 7.449 jiwa; 4 dusun dengan 12 RW dan 61 RT; tenaga } \\
\text { pendidik berjumlah 61 sedangkan murid berjumlah 1.385 tersebar di } \\
\text { tingkat TK sampai SLTP; sebanyak 1.297 orang tergolong PMKS }\end{array}$ \\
\hline Ekonomi & $\begin{array}{l}\text { 80\% bekerja di sektor pertanian dan perkebunan, sisanya } \\
\text { perdagangan; perempuan lebih banyak sebagai ibu rumah tangga, } \\
\text { sebagian kecil berprofesi TKW ke luar negeri; angkatan kerja } \\
\text { sebanyak 2.331 orang, penyaluran tenaga kerja ke perusahaan/ } \\
\text { industri sebanyak 1.313 orang, selisih 770 orang berstatus } \\
\text { pengangguran. Pencari kerja laki-laki sebanyak 871 orang dan } \\
\text { perempuan 220 orang }\end{array}$ \\
\hline Kesehatan & $\begin{array}{l}\text { Mencakup medis, bidan 1 orang, dan partisipan sebanyak 28 } \\
\text { orang; kelahiran bayi sebanyak 137 jiwa dengan komposisi fertilitas } \\
\text { berjumlah 137 orang dan mortalitas nol }\end{array}$ \\
\hline Sosial dan & $\begin{array}{l}\text { Mempunyai Karang Taruna dan Ikatan Olahraga dan Seni Formil di } \\
\text { tingkat desa/kabupaten; kelompok budaya dan kesenian; perayaan } \\
\text { hari besar keagamaan' belum adanya objek wisata yang terorganisir } \\
\text { dan unggul }\end{array}$ \\
\hline Infrastruktur & $\begin{array}{l}\text { Sarana peribadatan: masjid, mushola, langgar, dan madrasah; } \\
\text { pasar, toko, warung, dan perusahaan; jalan yang belum teraspal; } \\
\text { keterbatasan sinyal; sarana pengairan dan keirigasian, mata air } \\
\text { Non-PAM; 90\% sudah tersambung dengan jaringan listrik }\end{array}$ \\
\hline
\end{tabular}


Tabel tersebut menunjukkan bahwa adakondisi-kondisi yang telah memenuhi kriteria ideal di masyarakat, namun beberapa kondisi justru sebaliknya. Sehingga, dorongan potensial desa perlu dinotifikasi oleh tokoh desa, aparatur desa, dan masyarakat agar segera merumuskan langkah-langkah konkret dan sinergis dalam upaya membangun desa yang berkualitas.

\subsection{Temuan Karakteristik Proses Sosial Masyarakat Desa Mekarwangi}

Hubungan dan proses sosial adalah dua hal yang tidak dapat dipisahkan, ketika berbicara tentang hubungan maka proses sosial menjembataninya hingga berlanjut pada aktivitas yang saling mempengaruhi satu sama lain. Proses sosial diawali dengan interaksi sosial berupa hubungan timbal-balik yang dinamis antara pihak-pihak terkait baik dalam kerja sama, persaingan, atau pertikaian (Priyatna, 2013: 70). Sedangkan aktivitas interaksi yang memicu variasi hubungan dalam masyarakat disebut dengan proses sosial (Dirdjosisworo, 1982: 53). Sesungguhnya tujuan awal dari berlangsungnya hubungan dan proses sosial adalah untuk memenuhi kebutuhan dasar, kebutuhan akan kontrol sosial, dan kebutuhan afeksional dari tiap-tiap individu sesuai dengan latar belakang statusnya (Wulansari, 2012: 35).

Temuan di lapangan menunjukkan status dan peran masyarakat berprofesi di sektor pertanian, seperti kopi, kentang, sawi putih, cabai dan sebagainya. Hal ini linier dengantarafpendidikanmasyarakat yang masih rendah, sedangkan profesi petani tidak menuntut skill tinggi. Selain itu, masyarakat mempunyai stigma bahwa bekerja sebagai petani masih cukup untuk memenuhi kebutuhan sehari-hari. Dengan demikian terdapat rendahnya dorongan motivasional masyarakat untuk mengupayakan dirinya memperoleh status yang lebih tinggi melalui jalur pendidikan. Di sisi lain, profesi petani merupakan warisan keluarga yang mesti dilanjutkan secara turun-temurun.

Namun, berbeda halnya dengan tokoh masyarakat di desa Mekarwangi yang justru menempuh pendidikan tinggi. Ini disebabkan doktrin keluarga yang mengutamakan pendidikan anakanaknya, serta didukung dengan modal finansial yang cukup. Tokoh masyarakat ini sebetulnya memiliki profesi yang tidak jauh berbeda dengan masyarakat lainnya, yakni bertani. Perbedaannya ada pada kepemilikan lahan, usaha lain yang mendukung perekonomian keluarga, prestasi di bidang pendidikan, dan kemampuan komunikasi yang mumpuni. Terlebih jika telah bergelar haji, maka individu tertentu memiliki dua status sekaligus, yakni tokoh agama dan masyarakat. Keunggulan intelektual dan personal menjadikan orang-orang ini sebagai pemimpin di forum musyawarah maupun delegasi kampunga atau desa untuk menyampaikan aspirasi masyarakat ke aparatur desa.

Setiap tindakan manusia akan membentuk hubungan baru, baik permanen maupun temporal. Susunan tindakan yang diterima secara normatif akan membentuk golongan-golongan berdasarkan lingkup fungsinya, seperti golongan keluarga, ekonomi, sosial dan politik, maupun perhimpunan (Shadily, 1993: 96). Adapun masyarakat desa memiliki pola hubungan sosial yang 
terjalin dengan baik dengan ikatan sosial masyarakat pedesaan tergolong sangat erat dan pola interaksi yang cenderung bersifat sosial dan tradisional. Umumnya, aktivitas yang dilakukan bersama oleh masyarakat, seperti kerja bakti, gotongroyong, pengajian, dan pesta panen dimungkinkan karena kesamaan dalam mata pencaharian, yaitu sebagai petani, yang dijadikan sebagai landasan penguat tali silaturahim dan rasa solidaritas yang tinggi (Jamaludin, 2015: 88).

Proses sosial merupakan proses hubungan yang dinamis dalam bermasyarakatdenganmengombinasikan aksi-aksi sosial (interaksi sosial) sebagai pengaruh timbal-balik antara dua pihak atau lebih demi mencapai tujuan tertentu (Abdulsyani, 2012: 151). Prasyarat interaksi sosial adalah hubungan sosial antara dua posisi dalam proses komunikasi: komunikator dan penerima. Perspektif kedua berfokus pada hubungan sosial yang relevan lain dari komunikator atau penerima

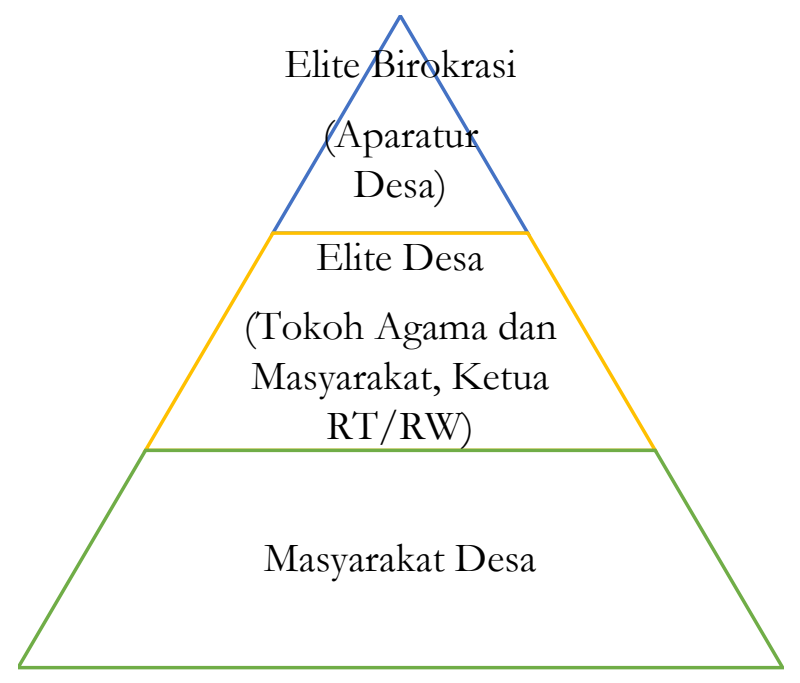

(Sumber: Setyani, 2017)

Gambar 3. Karyawan merapikan sisa busana di Lotus Department Store. dan pengaruh mereka pada asal-usul atau hasil komunikasi. Ketika kita berpartisipasi dalam proses komunikasi, kita tidak hanya komunikator atau penerima. Sebaliknya, kita juga masih anggota kelompok sosial yang berbeda dan masih terintegrasi dalam jaringan yang relevan hubungan sosial (Scherer, 2012).

Karakteristik khusus dari komunikasi berupa penggunaan isyarat fisik dan simbolik yang telah diakui keabsahannya oleh masyarakat (Narwoko \& Bagong Suyanto, 2011: 17). Dalam prosesnya, interaksi sosial dapat bersifat asosiatif dan disosiatif. Asosiatif mengarah pada integrasi sosial melalui fase akomodasi, kerja sama, koordinasi, dan asimilasi. Sedangkan disosiatif mengarah pada disintegrasi melalui fase kompetisi, kontravensi, dan konflik (Abidin \& Safe'i, 2003: 108).

Hubungan dengan proses sosial yang bersifat asosiatif dapat diketahui melalui aktivitas sosial di bidang pertanian dan perkebunan. Masyarakat desa Mekarwangi mempunyai kesadaran kolektif yang kuat. Dibuktikan dengan sikap gotong-royong dalam kegiatan peringatan hari-hari besar keagamaan, hari besar negara, acara pernikahan, pemakaman, pengajian, pembangunan rumah warga dan infrastruktur desa lainnya. Pembagian tugas dilakukan secara sederhana, pihak laki-laki bertugas mengerjakan pembangunan, sedangkan ibu-ibu menyiapkan makanan/cemilan. Doktrin yang dianut bahwa mereka yang tinggal di satu desa juga merupakan satu keluarga atas dasar kesamaan dari segi agama, budaya, bahasa, dan pekerjaan.

Penguatan kapasitas spiritual turut dilakukan dengan mengadakan 
pengajian rutin dua kali seminggu. Jika ada acara pernikahan, pihak keluarga akan meminta bantuan ke saudara atau tetangga dekat untuk menyiapkan hidangan walimah secara bersamasama. Jika ada tetangga atau kerabat yang meninggal, masyarakat akan mengunjungi rumah duka dan mengikuti pengajian yang dijadwalkan. Biasanya tamu yang berziarah akan memberikan bahan-bahan sembako kepada keluarga yang berduka, kini bantuan diberikan dalam bentuk makanan siap santap atau nasi kotak. Hubungan asosiatif juga terlihat antara pemilik modal dengan pekerjanya. Para pekerja diizinkan untuk mengambil sembako penjual atau pemiliknya dan akan dibayarkan seminggu setelah mereka memperoleh upah dari mengumpulkan hasil panen. Hubungan resiprokal semacam ini dikenal dengan istilah patron-klien.

Hubungan dan proses sosial turut mendapatkan perhatian khusus dari teoritisi sosiologi dengan maksud guna memberikan analisa komprehensif dan ilmiah tentang karakteristik antaranggota dalam menjalani kehidupan sosial. Von Wiese melalui ajaran hubungan antara manusia dan manusia menunjukkan adanya variasi kedekatan antarindividu, entah bersifat rapat-renggang atau dekatjauh dengan merekonstruksi kondisi masyarakat. Hasilnya ditemukan empat macam hubungan, yaitu: 1) hubungan sesungguhnya (motif dan aksi berfusi); 2) hubungan yang tidak sesungguhnya (motif dan aksi kontradiktif);3) hubungan terbuka; dan 4) hubungan berkedok (hubungan yang tersembunyi) (Shadily, 1993: 97-98).

Proses disosiatif relatif tidak mengalami konflik atau perselisihan antarwarga. Asumsinya bahwa setiap masalahhakikatnyatidakperludiperbesar untuk menghindari keretakan hubungan. Banyaknya kesamaan di antara anggota masyarakat relatif meminimalisasi terjadinya akulturasi maupun asimilasi, karena mayoritas masyarakat tetap memproteksi ciri identitas budaya Sunda yang diturunkan dari setiap generasi. Kasus lainnya seperti tidak ditemukan adanya amalgamasi atau pernikahan beda etnis, karena mayoritas masyarakat menikah dengan orang-orang satu kampung/desa. Hal yang memungkinkan terjadi adalah kontravensi, karena beberapa pengalaman masyarakat seperti desas-desus, perdebatan politik, gosip, dan sentimen agama kadangkala mewarnai kehidupan masyarakat desa Mekarwangi. Oleh karena itu, untuk menghindari resisntensi antarwarga, maka penyelesaian kontravensi dilakukan melalui proses dialog dengan tokoh agama/masyarakat.

Proses sosial berkorelasi dengan pemikiran Simmel. Simmel menjelaskan bahwa masyarakat sebagai objek sosiologi yang berfokus mempelajari pola interaksi dan bentuk asosiasi sebagai sebuah proses, didasarkan pada fungsi sosialisasi untuk mengidentifikasi karakteristik kelompok tertentu berbasis struktur interaksi dan asosiasi. Dalam proses kerja sosial, masyarakat menggunakan instingnya yang berpeluang menghasilkan konflik dalam evolusi sosial. Aspek sosiologis dengan memanfaatkan pendekatan Simmel digunakan untuk mengidentifikasi masyarakat bukan hanya sebagai sistem yang terpisah, melainkan merupakan belasan dari hubungan sosial, yang 
memberikan ketertarikan individu (Kinloch, 2005: 155-156).

Simmel juga mengkalkulasi kualitas proses sosial melalui konsep diadik dan triadik. Baginya, diadik belum mempunyai struktur kelompok yang utuh sehingga sensasi individualitas masih tinggi. Sedangkan triadik mampu membentuk strukur kelompok independen yang dapat mengikat individu-individu. Peran pihak ketiga dapat menjadi penengah dalam proses akomodasi maupun pemicu konflik. Perkembangan triade lebih lanjut dapat membangun struktur-struktur yang lebih kompleks, seperti masyarakat (Ritzer, 2012: 285).

Secara umum, proses sosialisasi masyarakat terjadi dalam kegiatan sehari-hari, seperti bertukar sapa tanpa mengobrol karena disibukkan aktivitas sebelum maupun sesudah bekerja. Bentuk sapaan yang biasa diucapkan tatkala berpapasan seperti "punten" atau sapaan dalam bentuk lain seperti "bade kamana bu/pak?" Untuk menjaga hubungan silaturahmi di antara tetangga, maka warga biasanya mengadakan makan bersama ketika ada waktu luang. Selain itu, sosialisasi juga dilakukan melalui saluran keluarga, sekolah, pemerintah desa, dan keagamaan.

Sosialisasi pertama kali dilakukan di tingkat keluarga, maka perubahan karakter seseorang ditentukan pada tingkat ini. Akan tetapi, banyak anggota keluarga seperti ayah dan ibu kurang menyadari bahwa tutur kata dan sikapnya dapat dengan mudah diduplikasi oleh anak atau sebaliknya rutinitas bertani dari pagi sampai sore akan sangat mengorbankan kasih sayang dan penanaman moral kepada anak. Pada akhirnya, kontrol terhadap aktivitas anak berkurang dan berpeluang menciptakan segresi maupun maupun deviasi sosial jika salah pergaulan.

Adapun sosialisasi antara warga dengan aparatur desa tetap terjalin, seperti melalui workshop/seminar kewirausahaan dan bercocok tanam maupun pemberian bibit gratis kepada petani di desa Mekarwangi. Hal ini dilakukan karena lahan di wilayah tersebut sudah mulai gundul, sehingga melalui bantuan tersebut secara tidak langsung pemerintah berusaha melakukan sosialisasi agar masyarakat bisa menjaga dan melestarikan lingkungannya.

\subsection{Proses Sosial: Menuju Reorientasi Sublimasi Masyarakat Pedesaan}

Ketika mendiskursifkan masyarakat desa, kerapkali kita merefleksikannya sebagai kelompok statis. Padahal, sifat dari makhluk sosial relatif mengalami perubahan. Bahkan, hubungan dan proses seharusnya menjadi akses perubahan masyarakat pedesaan itu sendiri. Dengan melihat adanya probabilitas dialektis dalam konsep pola-pola proses sosial dan terbukanya peluang dinamis masyarakat pedesaan, maka diperlukan pembuktian lebih lanjut.

Hubungan sosial berfungsi untuk mendeskripsikan kondisi dua orang yang terbawa dalam proses perilaku dengan saling mengkalkulasi benefit dari eksistensinya. Orientasi mutual yang diproduksi dapat berbentuk asimetris maupun simetris tergantung pada pencapaian tujuan bersama dan transitor karena tingkat stabilitasnya yang berbeda (Syam, 115-117). 
Bagaimanapun juga, proses sosial turut melatarbelakangi dinamika masyarakat. Yang menjadi persoalan krusial dari itu semua adalah bagaimana proses sosial dapat bekontribusi terhadap sublimasi masyarakat itu sendiri. Sehingga, fragmen suatu pembangunan desa dapat dikalibrasi secara komprehensif.

Berkiblat pada ilustrasi petani di Indonesia dengan semangat gotongroyong yang berkorelasi positif maupun negatif dalam pembangunan berupa tiga asumsi dasar: 1) setiap individu mengalami dependensi; 2) individu harus membantu sesama; dan 3) individu harus setara dengan anggota masyarakat lainnya (Sajogyo \& Sajogyo, 2011: 11). Kondisi demikian memaksa hubungan akan terus berlangsung selama anggota-anggota masyarakat merasa tidak dirugikan dalam kehidupan kelompoknya atau keuntungan dipandang lebih besar daripada kerugian yang diterima (Susanto, 1999: 105).

Dengan mengorganisir informasi dari Kepala Desa dan KASI Kesejahteraan, diperoleh beberapa poin penting terkait dengan peningkatan taraf sosial-ekonomi masyarakat. Memang, di era terkini, KASI Kesejahteraan memiliki peran sentral dalam memfasilitasi masyarakat dengan memberikan pengaduan satu pintu melalui RW. Setiap laporan yang masuk akan dianalisis dan dilakukan intervensi. Kekuatan ekonomi desa Mekarwangi didominasi oleh sektor pertanian terkhusus kopi yang pendapatannya dapat dikelola oleh BUMDes.

BUMDes sendiri mulai beroperasi tahun 2014 dengan fokus pembangunan ekonomi desa. Lembaga tersebut mengayomi berbagai varian komoditas pertanian. Ada pula sirkulasi pertanian melalui tengkulak yang mendanai petani dan hasilnya dijual kembali ke pemodal. Begitu pula dengan harga komoditas ditentukan oleh tengkulak sesuai amanat perjanjian antarpihak. Desa Mekarwangi juga difasilitasi dengan koperasi desa hingga beranggotakan warga yang berasal dari Ciwidey dan Celeuit.

Potensi kopi yang menggiurkan mendorong pihak kapital membangun pabrik pengolah kopi java preanger di desa Mekarwangi. Sebagaimana yang diketahui bahwa kopi java preanger adalah kopi berkualitas dan telah didistribusikan ketingkat regional maupun mancanegara. Bagi desa Mekarwangi sendiri, kopi ini mendapat predikat kedua terbaik seKabupaten Bandung Barat. Supervisi pengolahan produksi kopi dilakukan oleh pemerintah kabupaten dan desa.

Lembaga sosial desa Mekarwangi lainnya yang beroperasi bersifat interplay karena dikelola atas inisiatif masingmasing delegasi RT/RW melalui disposisi proposal dan portofolio. Alurnya dengan mengadakan musyawarah RT/RW/ Dusun lengkap dengan bukti berita acara, daftar hadir, dan foto. Biasanya diawali dengan alokasi pendanaan, perencanaan, observasi, supervisi, dan evaluasi program. Seperti kasus pembangunan infrastruktur jalan yang dilakukan secara gotong-royong. Dana material ditopang oleh desa, sedangkan biaya tambahan berasal dari masyarakat. Hal ini dilakukan untuk memaksimalkan dana yang ada dan dipantau oleh aparatur desa.

Namun, ada beberapa kendala struktural yang dihadapi oleh masyarakat desa Mekarwangi, antara lain gangguan bantuan distribusi listrik (Kwh) karena diskrepansi data antara desa dengan kabupaten; sinyal dan jaringan internet 
yang sangat terbatas; serapan anggaran yang belum maksimal dari kabupaten ke desa; dan regulasi yang berubah-ubah menghambat anggaran pembangunan. Pernah satu waktu, karena terhambatnya aliran dana, pemerintah desa mengambil langkah diskresi dengan meminjam dana dari aparatur desa untuk pembelian material agar tidak menghambat progres pembangunan infrastruktur.

Berdasarkan informasi tersebut, jelas bahwa isu masyarakat desa menempati ruang yang begitu kompleks, setidaknya berotasi pada tiga aspek penting, yakni: ekologi politik, ekonomi, dan relasi antara manusia dengan alam sekitar (Dharmawan, 2007). Dinamisasi masyarakat desa menghadapi tantangan nyata berupa marjinalisasi pedesaan, seperti perlambatan pembangunan dan marginalisasi pertanian(Wiesinger, 2007). Oleh karena itu, potensi desa seperti pemanfaatan lahan yang kurang strategis perlu dituntaskan untuk menghadapi era perubahan sosial (Williams \& Schirmer, 2012).

Beberapa carayang dapatditawarkan seperti industrialisasi pertanian guna menyediakan kesempatan kerja dan memperkuat modal sosial masyarakat lokal (Sawitri \& Soepriadi, 2014). Penguatan kapasitas fungsional lokal juga dapat dilakukan dengan memfasilitasi masyarakat melalui sosialisasi intensif serta pemberdayaan ekonomi kreatif dan kewirausahaan (Herlina, 2014; Munoz, Steiner, \& Farmer, 2014). Jika memungkinkan, antara lembaga, petani, dan teknologi agroforestri dapat dikombinasikan sekaligus untuk mengkreasikan sistem pertanian diversifikatif (Bacon, Getz, Kraus, \& Montenegro, 2019). Faktor lain yang kadangkala luput dari radar penguasa adalah peningkatan mutu pendidikan remaja di desa yang sebetulnya dapat meningkatkan taraf hidup masyarakat (Adedokun \& Balschweid, 2008).

$$
\text { Asumsi tersebut dapat }
$$

diimprovisasi dengan melibatkan stakeholders yang presisi dalam mengatasi persoalan kesejahteraan masyarakat, salah satunya adalah aktor yang handal di bidang teknokratis. Kalangan teknokrat berkontribusi dalam mentransmisikan ilmu pengetahuan dan teknologi dalam mendesain keinginan masyarakat (Nurdin, Devianty, Tia, \& Muchammad, 2015). Sehingga, sangat cocok dikombinasikan dengan prinsip ekowisata yang mampu mengefisiensikan ekonomi, keadilan, dan keberlanjutan ekologis tanpa merusak tatanan komunal serta menstimulus peredaran uang di pedesaan (Mbaiwa \& Stronza, 2009).

Harapannya, eksistensi pihak eksternal dapat memanipulasi dan mengkatalisasi performa masyarakat desa, sehingga berkontribusi pada peningkatan modal sosial yang adaptif dalam mengkonstruksi jaringan translokal untuk membangun sistem resiliensi, sumber daya, diseminasi informasi, dan pengetahuan yang pararel dengan tuntutan pembangunan infrastruktur dan teknologi berkelanjutan (Kusumastuti, 2015; Rockenbauh \& Sakdapolrak, 2019).

\section{IV.SIMPULAN}

Dari proses penelitian yang telah dilakukan, ada beberapa hal yang dapat disimpulkan, antara lain: 1) hubungan antarwarga masyarakat bersifat resiprokal berupa strata patron-klien antara tokoh agama/masyarakat dengan 
rakyat biasa. Hanya saja, patron-klien dinilai positif karena memberikan benefit sosial; 2) Dependensi terhadap tokoh agama/masyarakat membuktikan bahwa masih minimnya kontribusi pemerintah desa, baik karena faktor birokrasi maupun politis;3) proses sosial berlangsung secara asosiatif (gotong-royong, simpan-pinjam via koperasi, dan hajatan keagamaan maupun hari-hari besar) dan disosiatif (desas-desus dan perbedaan kepentingan pribadi). Sedangkan akar sublimasi mesti direorientasi ke sisi teknokratis dengan mengkreasikan industrialisasi pertanian berbasis lokal, pemberdayaan ekonomi kreatif dan kewirausahaan, pendidikan remaja desa, dan ekowisata.

\section{DAFTAR PUSTAKA}

Abdulsyani. 2012. Sosiologi: Skematika, Teori, dan Terapan. Jakarta: Bumi Aksara.

Abidin, Zaenal, \& Safe'i, Agus Ahmad. 2003. Sosiophologi: Sosiologi Islam Berbasis Hikmah. Bandung: Pustaka Setia.

Adedokun, Omolola \& Balschweid, Mark. A. 2008. Community Social Interactive Processes and Rural Adolescents' Educational Outcomes: What We Know and What We Need to Know. The Online Journal of Rural and Policy Vol 3 (2): 1-19.

Amin, Khairul. 2017. Elit dan Kekuasaan pada Masyarakat Desa (Studi Relasi Antara Pemerintah dan Masyarakat di Desa Rias Kecamatan Toboali Kabupaten Bangka Selatan Provinsi Kep. Bangka Belitung. Jurnal Sosiologi USK (Media Pemikiran \& Aplikasi Vol 11 (2): 167-187.

Bacon, Christopher M., Getz, Christy, Kraus, Sibella, Montenegro, Maywa, \& Kaelin Holland. 2019. The Social
Dimensions of Sustainability and Change in Diversified Faming Systems. Ecology and Society Vol 17 (4): 41.

Dharmawan, Arya Hadi. 2007. Dinamika Sosio-Ekologi Pedesaan: Perspektif dan Pertautan Keilmuan Ekologi Manusia, Sosiologi Lingkungan, dan Ekologi Politik. Sodality: Jurnal Transdisiplin Sosiologi, Komunikasi, dan Ekologi Manusia Vol 1 (1): 1-40.

Effendi, Tajuddin Noer. 2013. Budaya Gotong-Royong Masyarakat dalam Perubahan Sosial Saat Ini. Jurnal Pemikiran Sosiologi Vol 2 (1): 1-18.

Fitriani, Cicik. 2014. Interaksi Sosial TransmigranJawadenganMasyarakat Lokal di Desa Kayuagung Kecamatan Mepanga Kabupaten Parigi Moutong. E-Journal Geo-Tadulako UNTAD Vol 2 (1): 1-13.

Giddens, Anthony \& Sutton, Philip W. 2017. Essential Concepts In Sociology. Cambridge: Polity Press.

Halik, Ikin. 2014. Analisis Pola Interaksi Masyarakat Pendatang terhadap Masyarakat Lokal di Sumbawa Barat (Studi di Kecamatan Maluk, Sumbawa Barat, NTB) (Universitas Islam Negeri Syarif Hidayatullah Jakarta).

Herlina. 2014. Interaksi Sosial Penyuluh Pertanian sebagai Upaya Peningkatan Usaha Tani Masyarakat Petani di Kabupaten Batang. Journal of Educational Social Studies Vol 3 (2): 30-37.

Jamaludin, Adon Nasrullah. 2015. Sosiologi Perdesaan. Bandung: Pustaka Setia.

Khotimah. 2016. Interaksi Sosial Masyarakat Islam dan Kristen di Dusun IV Tarab Mulia Kecamatan Tambang Kabupaten Kampar. Kutubkhanah: Jurnal Penelitian Sosial Keagamaan Vol 19 (2): 241-249.

Kinloch, Graham C. 2005. Perkembangan dan Paradigma Utama Teori Sosiologi. (Dadang Kahmad, Penerjemah). Bandung: Pustaka Setia. 
Kusumastuti, Ayu. 2015. Modal Sosial dan Mekanisme Adaptasi Masyarakat Pedesaan dalam Pengelolaan dan Pembangunan Infrastruktur. Masyarakat: Jurnal Sosiologi Vol 20 (1): 81-97.

Masuku, Jakaria. S., Pattiselanno, August. E., \& Thenu, Stephen. F. W. 2017. Interaksi Sosial: Studi Kasus Perubahan Sosial di Kabupaten Kepulauan Sula Provinsi Maluku Utara. Agrilan: Jurnal Agribisnis Kepulauan Vol 5 (2): 101-113.

Mbaiwa, Joseph E., \& Amanda, L. Stronza. 2009. "The Challenges and Prospects for Sustainable Tourism and Ecotourism in Developing Countries." In The Stage Handbook of Tourism Studies, by T. Jamal and M. Robinson (eds.), 333-53. London: Sage.

Mocodompis, Jemmy R. 2014. Pola Interaksi Sosial Masyarakat dalam Menunjang Pelaksanaan Pemerintahan Desa (Studi Kasus di Desa Pokol Kecamatan Tamako Kabupaten Kepulauan Sangihe). Jurnal Politico Vol 1 (6): 1-13.

Munoz, Sarah-Anne, Steiner, Artur, \& Jane Farmer. 2014. Processes of community-led social enterprise development: learning from the rural context. Community Development Journal Vol 50 (3): 478-493.

Muslim, Asrul. 2013. Interaksi Sosial dalam Masyarakat Multietnis. Jurnal Diskursus Islam Vol 1 (3): 484-494.

Mutmainnah. 2009. Interaksi Sosial Masyarakat Desa Kauman dengan Masyarakat Pendatang dalam Tradisi Ziarah di Makam Sunan Kudus (Universitas Islam Negeri Sunan Kalijaga Yogyakarta).

Ortega, Rocio Rocales. 2019. Urban-Rural Relations in the Central Region of Mexico: A Viewpoint from Tlaxcala. Urbani Izziv Vol 23 (5): 11-21.

Nurcahyaningsih, Resta. 2014. Pola Interaksi Sosial Masyarakat Urban di
Desa Tanggulangin Kab. Kebumen (Studi Kasus tentang Interaksi Sosial Masyarakat Urban Desa Tanggulangin Kab. Kebumen) (Universitas Islam Negeri Sunan Kalijaga Yogyakarta).

Profil Desa Mekarwangi Kecamatan Sindangkerta Kabupaten Bandung Barat Tahun 2018.

Rahman, Adi. 2016. Perubahan Budaya Bergotong-royong Masyarakat di Desa Santan Tengah Kecamatan Marangkayu. EJournal SosiatriSosiologi Vol 4 (1): 86-99.

Raymond, Christopher M., \& Cleary, Jean. 2019. A Tool and Process that Facilitate Community Capacity Building and Social Learning for Natural Resource Management. Ecology and Society Vol 18 (1): 25.

Ritzer, George. 2012. Teori Sosiologi (Dari Sosiologi Klasik Sampai Perkembangan Terakhir Postmodern). (Saut Pasaribu, Rh. Widada, \& Eka Nugraha, Penerjemah). Yogyakarta: Pustaka Pelajar.

Rockenbauch, Till, \& Sakdapolrak, Patrick. 2019. Social networks and the resilience of rural communities in the Global South: a critical review and conceptual reflections. Ecology and Society Vol 22 (1): 10.

Safira, et al. 2019. "Laporan Praktikum Sosiologi Pedesaan." Makalah disampaikan dalam Kuliah Umum Sosiologi Pedesaan, Jurusan Sosiologi Fakultas Ilmu Sosial dan Ilmu Politik Universitas Padjadjaran, Bandung, 2019.Sajogyo \& Sajogyo, Pudjiwati. 2011. Sosiologi Pedesaan Kumpulan Bacaan. Yogyakarta: Gadjah Mada University Press.

Sawitri, Dewi, \& Soepriadi, Ishma Fathimah. 2014. Modal Sosial Petani dan Perkembangan Industri di Desa Sentra Pertanian Kabupaten Subang dan Kabupaten Karawang. Jurnal Perencanaan Wilayah Dan Kota Vol 25 (1): 17-36. 
Scherer, Helmut. 2012. Communication as a Social Process. Journal of Mass Communication \& Journalism Vol 2 (8): $1-2$.

Shadily, Hassan. 1993. Sosiologi Untuk Masyarakat Indonesia. Jakarta: Rineka Cipta.

Sukardi, Ahmad. 2015. Dakwah pada Masyarakat Pedesaan (Suatu Tinjauan Sosiologis). Al-Munzir Vol 8 (2): 129-144.

Susanto, Astrid Sunarti. 1999. Pengantar Sosiologi dan Perubahan Sosial. Jakarta: Binacipta.

Syahir, Mochamad. 2015. Dampak Interaksi Sosial Antara Pengunjung dengan Masyarakat Setempat di Lingkungan Lembanna, Kelurahan Pattapang, Kecamatan Tinggimoncong, Kabupaten Gowa (Universitas Hasanuddin).
Syaifudin, Imam. 2017. Interaksi Sosial dalam Membangun Toleransi Antar Umat Beragama di Dusun Dodol Desa Wonoagung Kecamatan Kasembon Kabupaten Malang (Universitas Islam Negeri Maulana Malik Ibrahim Malang).

Sztompka, Piotr. 2014. Sosiologi Perubahan Sosial. (Alimandan, Penerjemah). Jakarta: Prenada.

Wiesinger, Georg. 2007. The importance of social capital in rural development, networking and decision-making in rural areas. Journal of Alpine Research Vol 95 (4): 1-13.

Williams, Kathryn J. H., \& Jacki Schirmer. 2012. Understanding the relationship between social change and its impacts: The experience of rural land use change in south-eastern Australia. Journal of Rural Studies Vol 28 (4): 538548. 